Man and Nature

L'homme et la nature

\title{
Physiological Mechanism from Boerhaave to Haller
}

\section{François Duchesneau}

Volume 1, 1982

URI : https://id.erudit.org/iderudit/1011804ar

DOI : https://doi.org/10.7202/1011804ar

Aller au sommaire du numéro

Éditeur(s)

Canadian Society for Eighteenth-Century Studies / Société canadienne d'étude du dix-huitième siècle

ISSN

0824-3298 (imprimé)

1927-8810 (numérique)

Découvrir la revue

Citer cet article

Duchesneau, F. (1982). Physiological Mechanism from Boerhaave to Haller. Man and Nature / L'homme et la nature, 1, 209-218.

https://doi.org/10.7202/1011804ar

Copyright (c) Canadian Society for Eighteenth-Century Studies / Sociéte canadienne d'étude du dix-huitième siècle, 1982
Ce document est protégé par la loi sur le droit d'auteur. L'utilisation des services d'Érudit (y compris la reproduction) est assujettie à sa politique d'utilisation que vous pouvez consulter en ligne.

https://apropos.erudit.org/fr/usagers/politique-dutilisation/ 


\section{Physiological Mechanism from Boerhaave to Haller}

Albrecht von Haller (1708-1777) was trained under Herman Boerhaave (1668-1738) who can be regarded as a dedicated iatromechanist. The influence of Boerhaave on Haller was well marked, as is indicated in the Praelectiones academicae (1739-1744), the very impressive collection of Haller's notes and commentaries to his teacher's Institutiones medicae (first published in 1708). However, in his Primae lineae physiologiae (first published in 1747) and Elementa physiologiae corporis humani (1757-1766), Haller took issue with central points of Boerhaavian doctrine, e.g. the general vascular model for tissues and membranes, the theory of generation, etc. Not only did the contents of physiological theory radically evolve (especially with the "De partibus corporis humani sensilibus et irritabilibus," 1752), but methodologies also tended to differ on some relevant points. In addition the subject matter of physiological analysis seems to have shifted in the transition. ${ }^{1}$

I will try and develop three theses relevant to that change in research programme:

(1) Boerhaave's methodology seems significantly incoherent when confronted with the principles of his physiological theory. Boerhaave tried to find a way of reconciling these two differing tendencies of his thought.

(2) Some iatromechanist doctrines were already beginning to incorporate theoretical elements that did not seem compatible with a mechanistic analysis. I refer specifically to Baglivi's fibre theory. The way Baglivi was proceeding must have seemed both progressive and regressive to someone like Haller, who was well aware of Boerhaave's problematic attempts to reconcile mechanistic theory with empirical methodology.

(3) Haller made a decisive step to resolve those conceptual problems at the time he renounced Boerhaave's doctrinal model in physiology. This step coincided with the advent of the irritability theory. However we can best account for it through an investigation of the initial tenets of the Elementa.

(1)

C. Daremberg describes Boerhaave's doctrine this way: "His theory echoes an iatromechanism [inherited from Pitcairne], blended with Hippocratism and with chemical medicine, according to a formula similar to Baglivi's."” 
This needs clarification and adjustment. True: Boerhaave's doctrine is a blend, but not a kind of glueing together of different types of systems. He had a significant model of the organism, but he had to frame the right type of methodology to build the theory. There is tension between his theoretical and methodological presuppositions. ${ }^{3}$ The geometric and mechanical analysis of motion should be used in the explanation of operations of solid parts articulated together, as well as in the explanation of the determined effects of fluids in the economy of organic parts. Boerhaave points out that "these actions are produced according to the hydrostatic, hydraulic, and mechanical laws." The mechanical model seems to suggest extending the laws of mechanics to the explanation of vital motions, since for a Cartesian physicist, such laws made for the intelligibility of all natural phenomena. But applying the rule of intelligibility of functions to organic operations depends on a theory which assumes that the ultimate structure of the live anatomic whole determines all those functions.

To solve this problem, the suggested key is an analysis of anatomic structures into their compounding parts: the system of functions, Boerhaave believes, is deducible from the nature of the elements. But since the mechanical model fails to connect the nature of each organic fluid with the operations depending thereon, it is necessary to call upon experience to provide data (e.g. from recording significant humoral phenomena and from observing chemical reactions between humoral parts and the various solid materials). This is not contradictory to Boerhaave's general methodological stand. He is critical of purely speculative hypotheses of the Cartesian type, and he finds himself in agreement with Newton's rejection of superfluous causes. Direct observation bears on the organic phenomena, and their variations according to either internal or external conditions. Rational investigation purports to reveal the concealed dispositions producing observable phenomena and determining the sequential operations in observable structures. Clear and determinate principles should articulate any inference from known to unknown. In his rectoral address of 1715, De comparando certo in physicis, Boerhaave summarizes such a view. ${ }^{4}$ As a matter of fact, the principles to guide inferences can only be provided by mechanics and physics, because only their concepts and experimental data enable us to ascertain the general and special powers of bodies. But, with Newtonian physics, some unknown material dispositions are invoked to justify a method of geometrical deduction from the observed order and quantitative features of phenomena. The "Hypotheses non fingo" tends to suggest a purely operational scope for scientific demonstration. Computation of the effects and mathematical inference from that computation are sufficient to set a system of laws without ontological support in the nature of causal agents, unknown and methodologically presumed unknowable. Suspending the ontological causal reference makes it possible to derive from an interplay of structures and forces a principle of explanation for the regularly observed phenomena. I do not mean that this is the ultimate interpretation of Newtonian methodology. It is rather an expression of what Boerhaave took it to mean.

Newton wanted to restrict the role of unknowns to serve as postulates in the 
general mathematical expression of mechanical phenomena and determinations to motion in the universe. Boerhaave will postulate species of functional attractions specified in accordance with the observed and experienced properties: "gravitas, magnetismus, electrica vis, salium efficacitas, seminum actio, singularium denique corporum vires." Indeed, he uses the Newtonian model to stress the difficulty of understanding the more special kinds of motions and to suggest that an unknown real element should be supposed in the internal disposition of submicroscopic parts to account for particular effects manifested in the phenomena. So, let us postulate internal dispositions in the material parts linked with the resulting effects by some significant connection, provided those phenomena are taken to conform to the general laws of mechanism.

Two axioms permit the use of such a postulate in physiological explanation. The first axiom is clearly stated in the explanation of reproduction, but it prevails elsewhere as well: there is an unexceptionable law of nature maintaining the identity of specific organic types, the consensus of compounding parts, and the modality of organization. There is teleological causality at the source of composition and activity for each type of organism. Newtonian methodology lets one leave behind the scene the determining conditions for enacting of the organic "project". The second axiom states the circularity of organic determinations. In the Institutiones, this axiom is presented as a mere empirical statement about the interconnection of anatomical parts. ${ }^{6}$ In the De comparando certo in physicis, the axiom evolves to mean that the action of individual parts is somehow determined by the whole structure, or rather, by a correlation of the unperceivable parts echoed at the level of the whole structure. This second axiom limits the possibility of deduction from the general principles of Mechanics. ${ }^{7}$ One must rely on the empirical features to show the type of order that corresponds to the integrative operation of organism. And so, general principles of geometrical kind cannot apply strictly to explain the causal disposition of minute parts resulting in the integrative activity. The presumed causal property, which had been defined in analogy with gravitational force, strays from the model to become a postulate of internal organicity based on an unknown principle.

Accordingly, one would tend to limit mechanistic explanation to the operational description of certain effects, that are accounted for, at a more basic level, by the general axioms of organic order. But, as a matter of fact, Boerhaave's system of physiology is more dogmatically mechanistic, partly because it had preceded the recasting of his methodology in Newtonian mould and partly because it employs a general vascular model to account for all elements of the organic structure and for all functions. Boerhaavian methodology would recommend analyzing and classifying the complex empirical data (1) with the help of mechanical concepts proper (stage of $D e$ usu ratiocinii mechanici in medicina, 1702), (2) with the help of physiological concepts framed in the analogy of Newtonian dynamical concepts (stage of De comparando certo in physicis, 1715). In building his system, Boerhaave tends to apply some a priori reductionist schemes (such as the vascular model), which show closer affinity with the theoretical practice of the Cartesian iatromechanists. 
(2)

My second point is that some late iatromechanist theories incorporated conceptual elements which were not reducible to the mechanist model. I will take the example of Baglivi's fibre theory, which opens, in a problematic fashion, the road to a new doctrine of the physiological element.

Giorgio Baglivi (1668-1707) starts from the "structural micrology" of the Malpighi school. He takes the functioning of organs to depend on juxtaposed machinulae of microscopic or submicroscopic size. His ambition is to relate a model of machinulae with the empirical data of pathology, collected according to Sydenham's method. ${ }^{8}$ The De fibra motrice et morbosa $(1700)$ is the first of the collection of essays in which Baglivi works out his fibre theory as the model applying to all physiological machinulae. ${ }^{9}$ From there, the doctrine develops along four lines: (1) an anatomical study of fibre structure in the different parts of the body; (2) an analysis of the general functioning conditions for the organism; (3) a determination of the dynamic properties in fibres; (4) an hypothesis on fibrillar motion. The structural analysis indicates two levels; plain fibres, which can be described more geometrico, and complex aequilibria of fibres, which cannot be accounted for geometrically: wherefore it is necessary to subordinate geometry to observation. References to mechanical analogues, such as the horologium oscillatorium, act as conjectural approximations of what the fibrillar machinulae are. The conjecture has then to be checked against the empirical functional features of the various organic systems. But Baglivi is convinced that the explanatory model for fibrillar activity should be built in conformity with a system of general functions for the whole organism. So, he contrives his dual system of integrated parts, combining either nervous fibres or membranous fibres jure originis, officii, consensus et societatis. ${ }^{10}$ The model refers to a twofold geometrical apparatus for mechanical activity, which strays from the professed empiricist methodology: the organic twin horologia oscillatoria are interpreted au pied de la lettre, and, as a matter of fact, the presumed discovery of contractile motions in the dura mater ("cor cerebri") 1 ties in with this same system. However, Baglivi is convinced that the essential motive force for the physiological clock is afforded by the fibrillar structure. The main role should be allotted to the systaltic and diastaltic motions in fibres, even if they remain unperceivable. The proportio impetus et resistentiae which the whole structures seem to display, suggests such an hypothetical point of theory.

This way, Baglivi initiates research into properties of the fibre "tanquam radicem, et principium partium." 12 He will show phenomena in the muscular fibres equivalent to what will later be identified with Hallerian irritability (experiments on excised heart, on fragments of the cardiac muscle). To explain such contractions, he does not appeal to the nervous fluid, but to a kind of spring inside the heart fibres. The facts are clearly evidenced. Whether we are faced with Hallerian irritability or not, is a matter of theoretical interpretation. The step in Haller's direction consists in severing the phenomenon from the activity of animal spirits, and linking it with a specific "mechanism" within fibres. But live fibrillar contraction is made to depend on the diffusion of an impulse through the whole horologium oscillatorium, which initiates from the dura mater as the organism's main 
spring. The property is also generalized to glands. And the other membranes, instead of being restricted to a mere wrapping function, are taken to exert oscillatory, dynamical, and equilibrating action. Indeed, fibres are presented as minute automata, which act as so many small levers, when stimulated by the contact of fluids, but those levers are activated by a first impulse coming from the centre, and they are kept in sufficient tension by the centre's oscillatory action.

When Baglivi tries to identify the property that resides in the fibre, he seems to resume Borelli's theory of muscular motion: organic parts are endowed with given quantities of moving force " $a$ varia gravitate ac minimorum componentium structura." 13 This way, phenomena of organic motricity are seen to depend on a nisus solidorum ad contractionem. Such a kind of representation serves to keep animistic or iatrochemical principles at bay. This iatromechanistic conviction, however, is mainly programmatic. To apply axioms of Mechanics to physiological phenomena, one must account for the functional features evidenced by macroscopic or microscopic observation and frame acceptable hypotheses on the structure of submicroscopic physiological elements: Necesse est in hoc practices negotio Geometra famuletur observationi. Baglivi tries some mechanical models to account for contraction in the muscle fibre. The inadequacy of such models is so evident that Baglivi calls them opiniones. In spite of the mechanical ideal, concepts creep in to describe the functional aspect of phenomena. (They will reappear in Haller's physiology to identify the fibrillar elements as irreducible organic structures). For instance, Baglivi states that the fibrarum crispatura, which he also calls solidorum irritatio, is produced by a limited variety of stimuli (within thresholds of variation), whether these stimuli be internal or external, natural or pathological. But, besides this prima facie functional characterization, the structural conditions for fibrillar properties exceeded Baglivi's possibilities for observation and demonstration. Vital contractility, as specific property, is interpreted within a very general framework of methodologically abstract mechanism. It may be noted that in the pathology part of the doctrine, vital contractility is assigned back to ancient Methodism and its couple strictum-laxum. As basic pathological states, spasm and atony express the proper dynamism of fibrillar structures. Curiously enough, this trend brings the anatomo-physiological analysis of fibrillar structure closer to the consensus of organic parts in the Hippocratic tradition.

This shows as well that a unitary model of organic function rules over Baglivi's explanations. Accordingly, was it really possible to grant distinct orders of fibres specific and autonomous properties? In contraposition to Baglivi's combined skepticism and mechanical dogmatism, Haller develops his theory of the elementary organic structures. He gives fibre theory a different meaning from Baglivi's by avoiding a priori reference to a global and unifying mechanical model. For Baglivi, fibre was a machinula functioning within an integrated machine, which was somehow considered to be the meaningful prototype. This global machinery would determine by interplay of antagonistic forces the functional activity of the machinulae in the mechanical harmony of the whole. With Haller, fibre becomes a 
physiological element endowed in certain cases with specific functional properties.

When the ultimate anatomic element, the fibre, becomes the substratum for a system of vital operations, physiology gets involved in studying vital motions and in taking account of the manifold arising therefrom. The definition which opens the Elementa physiologiae corporis humani bears witness to this trend. ${ }^{14}$ Physiological research must be based on the study of the anatomical structure on which vital motions depend. This structure may be compared with the ordering of wheels and cogs of a mechanism; in this respect the physiologist faces the material organization of his subject matter the way a mathematician aims at expressing in a calculus the interplay of forces and the mechanical functions: the operation can be achieved only insofar as the structure of parts may be analytically disassembled. However, the connection of motions with the so-called geometrical structure of organism raises problems which break precise analogy with the model to be inferred from mechanical investigations. Though physiology is the theory of motions taking place in the animated machine, and though principles of mechanics, hydrostatics, and hydraulics can apply, attempts at reduction hardly succeed because of specificity in the organic motive phenomena. ${ }^{15}$ The apparent mechanical anomaly in phenomena requires one to resort to an empiricist methodology. Haller does not reject the principle that the laws of Mechanics apply to forces and effects which experience identifies as specific to the living. But the transfer of principles and models must be subordinated to a systematic experience of vital phenomena that may indicate legitimacy conditions for applying the explanatory scheme. There seems to be incommensurable complexity between the circulatory function of blood in functionally diversified vessels endowed with tonicity, differential resistance, and special dynamics on the one hand, and the circulation of fluids in lifeless canalizations with standing properties on the other. Haller keeps a certain number of the iatromechanist hypotheses, which, by the way, experience confirms, but those corroborated hypotheses remain within bounds of a macroscopic analysis pertaining to elementary mechanics and geometry. This was the theoretical level of explanatory schemes in Borelli and Hales: there is no guaranty that one can proceed with this model of mechanical intelligibility beyond such a level. Haller adopts the same agnosticism in regard to calculus and probability measurement in application to the theory of vital motions: he relativizes the hoped-for results of a minute quantitative decomposition.

As a counterpart, Haller sets up a composite experimental methodology: use of comparative and pathological anatomy, microscopic investigation of elementary structures, organic devices made conspicuous through diverse preparation techniques, and above all, experiments on living animals. The aim is to establish, by means of correlated experiences at various levels, a determined connection between structure and function, in the numerous cases where first-hand description does not enable us to perceive clearly nor set precisely the functional correlations of vital motions. On the other hand, the principle of repetitive experimentation is to guaranty that through 
structure-function description, one can reach to an equivalent of organic laws. This is done by eliminating adventitious or casual phenomena which form sorts of parasitic qualitative variables. ${ }^{16}$ Indeed, Haller falls back on Bacon's methodology, but he cannot operate within the bounds of too strict an empiricism. He rejects hypotheses framed as a priori presuppositions to explain phenomena, but he maintains at the same time a role for hypotheses that have been suggested by experience, insofar as they determine explanatory schemes and analogy transfers from one field of observation to another: they may give meaning to facts that have been revealed by observation but seem to fall short of any direct empirical correlation. Experimentally controlling and classifying facts is not enough to render useless any attempt at theoretical systematization. Thus, a framework for analysis is afforded by a theory, or an hypothesis which anticipates the theory to be formulated. Converging and concurring facts warrant legitimate, though ever probabilistic, use of theoretical concepts. This is the case with Haller's views on the organic structure.

In the Primae lineae physiologiae (1747), Haller had stated his aphorism: physiology is anatome animata. This methodological paradox gets analyzed at the beginning of the Elementa. Since the Italian iatromechanists of the mid-seventeenth century, anatomy had been conceived as a descriptive science of structures which could make the deduction de usu partium possible. Haller will affirm that the order cannot be geometrical in the subject matter of physiology. ${ }^{17}$ From the geometer's method, Haller draws a distinction between degrees of truth, stretching from certainty to mere conjecture. And so, the definition of fibres as similar to elements in geometrical combinations is paradoxical. Haller's definition runs this way: "Fibre is for the physiologist what the line is for the geometer, scrire that which all figures derive from."18 Canguilhem's interpretation is that this doctrine of physiological element is jointly based on an analytic investigation of observable structures and on a rational jump to a unit of organisation according to the pattern of elements in Geometry. ${ }^{19}$ Fibre is a pluralistic and manifold genus of elements which could be indefinitely distinguished, a material homologous with the complex special features of organic wholes. Three quarters of a century before Haller, Malpighi, developing the methodological presuppositions of his micrology, had acknowledged the need for principles of integration to explain the structural anatomy of living beings. His principle of integration was a principle of mechanical explanation of phenomena expressed by the organism as a whole. It resulted in the notion of complex anatomical structures that might be reduced to a juxtaposition of machinulae. If the structure of machinulae and their mode of juxtaposition were known, could the function of the integrated systems be deduced ex hypothesi? Haller's definition of fibre ruins the possibility of such a deduction more geometrico, because the determination of what counts as a structural element depends on the special order of properties in physiological systems, and this order is to be told empirically. Analysis shows that the physical and chemical properties of fibre components could be given, but one must transcend the mechanico-chemical effects to account for the observed and concealed features of physiological phenomena. At this exact point, 
theoretical anticipation intervenes. Haller presumes that the element in the animal body is not the fibril shown by microscopic analysis, because such a fibril seems to be itself decomposable in yet smaller fibrils, but the element is an unperceivable fibril reached by the sole force of mind (sola acie mentis) which would not be itself divisible into further organic constituents.

I will be content at this stage to stress two features of the Hallerian analysis. First, the organic element is taken to be simple only insofar as it can account functionally for observable systems at a higher level: as "simple", it affords explanatory ground for the organic properties of structurally complex wholes. Haller enumerates all anatomical structures where fibrillar elements are observed, then he postulates a common nature for all those elements in the elementary or primordial fibre: "The fibre is elastic; flexible, it contracts and recovers its reduced size. This nature has been observed even in the bones, it would be made manifest generally, if one produced the separation of the most minute filaments." ${ }^{20}$ This kind of elasticity represents a basic physiological property corresponding to the fibrillar structure; it will determine, through integration of the organic systems, the enactment of complex functions. Indeed Haller, following indications of anatomical observation, will distinguish elasticity, as universal property of fibres, from irritability, which belongs to fibres of muscular tissues, and sensibility which is conditioned by the activity of the nervous network. Nevertheless, it remains significant that only the elasticity of primordial fibre appears as raison d'être of functions performed by integrated systems: this chemically complex fibre is a simple structure, if one analyzes the structural ground for organic functions.

The Hallerian model possesses a second noteworthy feature: the rational requirement that justification for the organic functions be sought for in a submicroscopic elementary structure. The theoretical extrapolation beyond observable data is not a mere inference justified by limited technical means; it is a logical requirement of the model of order referred to. ${ }^{21}$ On the one hand, microscopical observation gives evidence of fibrillar structures "emboîtées" one inside the next down to an infinitesimal order compared with global organic structures at the macroscopic level. If one relied on a methodology of strict anatome animata, it would mean a constantly widening gap between the physiological functions to be accounted for (at the global level) and the structural conditions to count in the mechanical explanation. In Hallerian physiology, objective explanation of the structure-function tie implies that the anatomic elements be homogeneous in their dispositional properties with organic wholes, provided one follows the thread of analogy with observed phenomena: otherwise, this science would reinstate substantial forms and occult qualities, or at least, Van Helmont's archeus and Stahl's logos.

Haller is a follower of Boerhaave, and Boerhaave himself felt that empiricist requirements of Newtonian methodology had to be extended to physiology. Haller must maintain this analogy with observed phenomena under his conception of natural order and his knowledge of data, even though the gap may seem to widen between global activities and elementary structures. And so, we have his postulate of a primordial fibre, itself unanalyzable in terms of structures emboittées, and, as such, inaccessible to microscopical investigation. But it affords the theoretical condition and 
paradigmatic element for integrating of complex structures, since it contains the dynamical raison d'etre of organic properties, and since it keeps within compass of analogy with the observed features of fibrillar components at an intermediate structural level.

This way, with Haller as well as with Maupertuis, but in a more experimental and structuralist perspective, tying in with a methodology of anatomia subtilis, a new concept is developed to represent the integrative order of organic structure.

The shift in theory and in method cleared the ground insofar as late iatromechanical models are concerned. It probably launched a new research programme which has supported physiological theorizing up to the advent of cellular physiology. It may help our understanding of that theoretical shift to have recalled Boerhaave's and Baglivi's ambiguous problematics, whence Haller deviated, not without further integrating in a complex fashion methodological and theoretical models, which had been initially cast in the mould of iatromechanism.

François Duchesneau

Université de Montréal

\section{Notes}

1 Arguments and textual evidence in support of my interpretation are presented here in a condensed form; they are more fully spelled out in my forthcoming book, La Physiologie des lumières (The Hague: Martinus Nijhoff, 1981).

2 C. Daremberg, Histoire des sciences médicales (Paris: J.B. Baillière, 1870), II, p. 889.

${ }^{3}$ Herman Boerhaave, Institutiones, $\S \S 40-41$, quoted by Daremberg, p. 892: "Les solides sont ou des vaisseaux qui contiennent les humeurs ou des instruments tellement construits, figurés et liés entre eux, qu'il se peut faire, par leur fabrique particulière, certains mouvements déterminés, s'il survient une cause mouvante. On trouve en effet dans le corps des appuis, des colonnes, des poutres, des bastions, des téguments, des cordes, des leviers, des aides de levier, des poulies, des pressoirs, des soufflets, des cribles, des filtres, des canaux, des auges, des réservoirs. La faculté d'exécuter des mouvements par le moyen de ces instruments s'appelle fonction; ce n'est que par des lois mécaniques que ces fonctions se font, et ce n'est que par ces lois qu'on peut les expliquer. Les parties fluides sont contenues dans les solides, mues, déterminées dans leur mouvement, mêlées, séparées, changées. Elle meuvent les vaisseaux avec les instruments qui sont liés avec eux; usent, changent leurs parois, et réparent les pertes qu'elles y ont causées. Ces actions se font selon les lois hydro-statiques, hydrauliques et mécaniques. On doit donc les expliquer conformément à ces lois, quand on est venu à bout de connaître auparavant la nature de chaque humeur en particulier, et les actions qui en dépendent uniquement, autant qu'on peut les découvrir par toutes sortes d'expériences."

4 Sermo academicus De Comparando Certo in Physicis . . (Lugduni.Batavorum: Apud Petrum Vander Aa, Bibliopolam, 1715), pp. 2-3: "Paucis enim conabor evincere, rerum principia omnino nos latere, solis noscuntur, aut quae ex his, una tantum hac via prius exploratis geometrici ratiocinii firmitate elici possunt."

5 Ibid., p. 19.

6 Institutiones, $\S 47,(1727)$, p. 15: "Verum omnia illa ita cohaerent inter se ut, quasi in orbem eundo, mutuas causae et effectuum vices agant."

7 De comparando certo in physicis, p. 38: "Omnia, nisi fallor, haec docent, humani corporis particulam simplicissimam a tot aliis pendere singulatim definitis, ut principiorum universalium usu nihil huic intelligendae prodesse queat, sola autem exempli praemonstratione fabricam patescere."

${ }^{8}$ This is evident in Baglivi's major treatise De praxi medica (1696). For the story of Baglivi's research on fibres, see M.D. Grmek, "La notion de fibre vivante chez les médecins de l'école iatrophysique," Clio Medica, 5 (1970), 297-318. 
${ }^{9}$ My analysis will be mainly based on Specimen de fibra motrice et morbosa, in quibus de solidorum structura, vi, elatere, aequilibrio, usu, potestate, et morbis disseretur (1702).

10 Opera omnia, 6e éd. (Parisiis: Apud Claudium Rigaud, 1704), p. 270.

"Ibid., p. 273, cf. p. 282: "dura mater, alterum quasi cor solidum validumque."

${ }_{12}$ Ibid., p. 268.

${ }_{13}^{13}$ Ibid., p. 321.

${ }_{14}$ Albrecht von Haller, Elementa physiologiae corporis humani, 8 vol., (Lausanne: M.M. Bousquet - F. Grasset; Berne, Societas typographica, 1757-1766), I, Praef. autoris, p. i: "Qui physiologiam scribit, corporis animalis internos motus, viscerumque munera, et humorum mutationes, et vires exponendas sumit, quibus vita sustentatur; quibus vicissim lacerti valent, qui mentis reguntur imperio; quibus alimenta in succos nostros, adeo varios, convertuntur; quibus demum ex iis succis, et nostra corpora conservantur, et humani generis jactura novis partubus reparatur."

15 Ibid., pp. V-VI: "Multa enim sunt in animali machina, quae a communibus legibus mechanicis valde aliena sunt: motus magni a parvis causis excitati; celeritas humorum per eas causas parum diminutae, a quibus per receptas leges frangi opportuerat: motus a causis penitus incognitis irrepentes: motus vehementes a debilibus fibris producti: decurtationes fibrarum omni calculo majores, et quae alia."

${ }^{16}$ Ibid., p. V: "Nullum unquam experimentum, administratio nulla, semel debet institui; neque verum innotescit, nisi ex constante repetitorum periculorum eventu. Plurima sunt aliena, quae se in experimenta inmiscent: discedunt ea repetendo, ideo quia aliena sunt, et pura supersunt, quae ideo perpetuo similiter eveniunt, quod ex ipsa rei natura fluant. Sed et natura variabilis est, et sola repetitione ejus quasi sensus et voluntas, dispalescit. Haec lex, prioribus temporibus parum perspecta, Morgagno inprimis auctore in anatomen illata est."

17 Ibid., I, p. 1: "[Physiologiae] auctorem plurima ex physicis, chemicis, anatomicis, aliisque artibus repetere necesse est: neque ipsi circa simplicia corpora, quae facillimae definitionis sint, unice versari licet, ut utroque modo a Geometra differat, qui suae artis principia ab ipsa arte sumat, et lineas punctaque, aliaque mirae simplicitatis elementa tractanda nactus sit."

${ }^{18}$ Ibid., I, p. 2.

${ }^{19}$ Cf. G. Canguilhem, La Connaissance de la vie, 2e éd., (Paris: Vrin, 1967), p. 51.

${ }^{20}$ Elementa, I, p. 8.

${ }^{21}$ Ibid., I, p. 7: "Ex his nunc elementis, terra, aqua, oleo, ferro et aere conjunctis fibra nascitur, elementum corporis animalis, invisibile ubi simplex, multo minus, quam quod microscopiorum vi augente adhibita oculis nostris subjici queat, cum minima animalia, quae ipsa vehementissima lentium et sphaerarum vitrearum vi aucta demum oculis nostris conspicua fiunt, tamen ipsa perinde fibris fiant, multo certe mole totius animalis minoribus." 